\title{
The Relationship Between Organizational Factors and Individual Innovation Performance: The Mediating Role of Proactive Behavior
}

\author{
Li Chunhui \\ College of Business Administration, Guangzhou Huashang Vocational College, Guangzhou, Guangdong, China \\ Email:1171119680@qq.com
}

\begin{abstract}
Innovation is an activity with high investment and high risk. The innovation performance of employees depends on their proactive behavior, but the positive leadership and support factors of the organization can not be ignored. Through 1050 questionnaires of scientific and technological employees, this paper empirically analyzes the mechanism of organizational positive leadership and supporting factors on employees' personal proactive behavior and innovation performance. The results show that organizational positive leadership and support factors have a significant positive correlation with employees' individual proactive behavior and innovation performance. Proactive behavior plays an intermediary role between organizational positive leadership and support factors and individual innovation performance.
\end{abstract}

Keywords: Positive leadership, Organizational support, Innovation performance, Proactive behavior

\section{INTRODUCTION}

With the intense competition and the expansion of external environmental uncertainty, most enterprises realize the importance of innovation for high-quality and sustainable development. Enterprise innovation should ultimately be implemented on various work behaviors of individual employees [1]. Relying solely on employees' passive implementation of work requirements and leaders' instructions can no longer meet the requirements of enterprise innovation and development, which requires every employee to have proactive behavior [2].

Innovation is an activity with high investment and high risk [3]. Employees' individual innovation performance depends on their proactive behavior, but the positive leadership and support factors of the organization cannot be ignored. However, the existing literature on the interaction mechanism between the positive leadership and support factors of the organization and employees' individual proactive behavior and innovation performance is still lacking, which is an urgent problem to be solved.

This study will take the scientific and technological personnel and college teachers engaged in R \& D in hightech enterprises in Dawan District, Guangdong, Hong
Kong and Macao as the research object, and try to study the occurrence mechanism of proactive behavior and the relationship between proactive behavior and individual innovation performance from the two aspects of organizational environment positive leadership and organizational support, so as to build an organizational environment active leadership An empirical research framework for the comprehensive impact of organizational support on proactive behavior of science and technology employees and the relationship between proactive behavior and innovation performance. In order to provide new knowledge for the development of proactive behavior theory, and on this basis, provide practical reference for enterprise managers to stimulate proactive behavior and improve innovation performance.

\section{LITERATURE REVIEW AND THEORETICAL ASSUMPTIONS}

\subsection{Organizational factors and individual innovation performance}

Positive leadership is a new concept developed to meet the new needs of the times for leadership [4]. Inclusive leadership is a leadership behavior characterized by openness, accessibility and accessibility in the interaction with subordinates [5], which can 
effectively promote the innovation atmosphere of the organization and team [6], and has a positive impact on the organization and employees [7]. Transformational leadership is a leadership behavior that arouses the highlevel needs of subordinates through idealized influence, charisma, intellectual stimulation and personalized care, so as to make them put organizational interests above personal interests, so as to show excellent performance [8], which helps to stimulate employees' potential, encourage employees to break the routine and try new ways to solve problems, It is conducive to the formation of an atmosphere of pursuing innovation in the organization [9]. Empowering leadership refers to the leadership behavior in which leaders share power with their subordinates [10], which can effectively improve employees' enthusiasm for innovation [11]. The above leadership style has been widely proved to have a positive effect on organizations and individuals, so it is called " positive leadership" [12].

Eisenberge (1986) believes that the sense of organizational support refers to "the overall feeling that employees in an organization attach importance to their contributions and care about their welfare" [13]. George (1993) believes that the sense of organizational support refers to "the assurance and confidence that employees get help from the organization when they work effectively and deal with stress situations" [14]. Bell et al. (2002) believe that the sense of organizational support is "employees' overall perception and belief in the recognition of employees by the organization, the recognition process of employees' performance and the corresponding treatment given to them" [15]. Ling Wenyun et al. (2006) believe that "the sense of organizational support is the employees' view of how the organization views their contributions and cares about their interests" [16]. To sum up, we believe that the sense of organizational support is the overall feeling of employees about the organization's help, welfare support and interest concerns. Because the sense of organizational support is to talk about the organization's support for employees from the perspective of employees, which has a direct and due effect on employees, the organizational support in this study refers to the sense of organizational support.

In the 1970s, foreign scholars began to study individual innovation performance. Amabile et al. (1996) believed that "individual innovation performance is the objective result of a series of novel ideas implemented within the organization" [17]. Janssen (2000) believes that "individual innovation performance is to improve organizational group performance, mainly the generation, introduction and implementation of new ideas" [18]. Han Yi (2006) believes that "individual innovation performance includes innovation willingness, innovation action, innovation suggestions, innovation achievements and innovation thinking dissemination" [19]. Heng Yuanyuan (2012) believes that "individual innovation performance is a series of individual innovation activities and their output, perceptible and measurable achievements that are valuable to the organization or team. These innovation activities need to go through various procedures or stages to produce performance" [20]. To sum up, we believe that individual innovation performance is the result of innovative ideas put forward and implemented by individual employees in order to improve enterprise performance.

Chen Wenpei (2014) found that leadership style has a significant positive impact on individual innovation performance [21]. Inclusive leadership style has a significant positive correlation with university scientific research performance [22]. Transformational leadership can affect employees' morale, ideals, interests and values, motivate employees to achieve performance higher than their initial expectations, and finally make them pay more attention to personal interests [23]. Empowered leadership can affect employees' task performance by influencing subordinates' self perception based on selfesteem and internal social status [24]. Janssen et al. (2004) found that organizational support can positively affect employees' innovation performance [25]. Yu et al. (2013) also confirmed the positive correlation between organizational support and employee creativity [26].

Through the above literature review and analysis, we speculate that positive leadership and organizational support can positively predict employees' individual innovation performance, so we assume:

$\mathrm{H} 1$ : there is a significant positive correlation between organizational factors and individual innovation performance.

H1a: positive leadership is significantly positively correlated with individual innovation performance.

$\mathrm{H} 1 \mathrm{~b}$ : there is a significant positive correlation between organizational support and individual innovation performance.

\subsection{Proactive behavior and individual innovation performance}

There are different views on the definition of proactive behavior. Crant (2000) believes that "proactive behavior is an employee's self initiated, expected and proactive work behavior" [27]. Campbell (2000) believes that "proactive behavior is the intentional behavior of employees who are future oriented and try to change their situation" [28]. Fay et al. (2001) believe that "proactive behavior is a self initiated and proactive work behavior" [29]. Parker et al. (2001) believe that "proactive behavior is an employee's spontaneous, expected behavior aimed at changing or improving their own situation or situation" [30]. Belschak (2010) and others believe that "proactive behavior is the tendency of employees' internal stability to affect environmental changes, can actively complete 
their work, and is willing to change the environment in time without environmental constraints" [31]. Fuller (2012) and others believe that "proactive behavior refers to spontaneous, future oriented and change oriented predictive behavior aimed at improving the environment or individual self" [32]. Based on the above points of view, we believe that proactive behavior is an individual employee's future oriented spontaneous change behavior.

Frese (2008) believes that "proactive behavior can have a key impact on individual innovation performance" [33]. If an individual can exercise autonomy at work, he will be more willing to try new ideas and his innovation performance is more likely to be improved [34].

According to the above literature review and analysis, we speculate that proactive behavior can positively predict employees' individual innovation performance, so we make the following assumptions:

$\mathrm{H}$ 2: proactive behavior is significantly positively correlated with individual innovation performance.

\subsection{Organizational factors and proactive behavior}

Liu Yang et al. (2016) found a significant positive correlation between inclusiveness and employee proactive behavior [35]. Strauss (2010) and other studies show that transformational leadership increases employees' self-evaluation of proactive behavior [36]; Den Hartog et al. (2012) found that transformational leadership can effectively promote employees' proactive behavior [37]. Leadership empowerment can promote employees' internal identity perception, make employees feel that their work content and contribution have been valued and supported by their superiors. It is an organizational "insider", so as to enhance employees' work motivation [38], improve employees' job satisfaction, strengthen organizational commitment, and enable employees to actively show their willingness to innovate and innovative behavior [24]. The sense of organizational support is the commitment of the organization, and the individual's perception of this commitment will affect their work and behavior performance [39]. If employees feel valued and cared by the organization, it will not only improve their sense of responsibility for carrying out routine work, but also increase their emotional investment in the organization, and even show independent innovation behavior without expected reward [40].

Based on the above literature review and analysis, we speculate that positive leadership and support factors in the organization can positively predict employees' proactive behavior, so we make the following assumptions:

H3: there is a significant positive correlation between organizational factors and proactive behavior effect.
H3a: there is a significant positive correlation between positive leadership and proactive behavior effect.

$\mathrm{H} 3 \mathrm{~b}$ : there was a significant positive correlation between organizational support and proactive behavior effect.

\subsection{Mediating role of proactive behavior}

Inclusive leadership encourages employees to make their subordinates feel cared for, supported and understood, which helps them improve their work performance. Transformational leaders promote employees' innovative performance by encouraging employees' self-expression, accepting unorthodox ideas, inspiring employees by example [41]; It also supports innovation, gives employees full autonomy, encourages creative thinking, and completes or improves work in new ways [42]. Amabile et al. Found that an important antecedent variable of employee innovation is to obtain the power to participate in decision-making and the perception of autonomy [43]. Authorization can enable employees to lead and make decisions independently [8]. In order to repay the organization, they often have a high level of task motivation, resulting in more innovative behaviors [44]. Mckenny (2013) found that organizational support should include three dimensions: respect (emotional) support, welfare support and instrumental support [45]. Organizational support has a positive impact on employees' work attitude, work performance, work engagement and organizational citizenship behavior; Tian Xizhou et al. (2010) believe that if employees can feel the support from the organization, they will have a more sense of responsibility for the tasks assigned by the organization, increase work investment in their work, and have a direct or indirect impact on employees' innovative behavior [39].

According to the above literature review and analysis, we speculate that organizational factors will affect employees' individual innovation performance through the intermediary of employees' proactive behavior. Therefore, we make the following assumptions:

$\mathrm{H} 4$ : proactive behavior plays an intermediary role in the relationship between organizational factors and individual innovation performance.

$\mathrm{H} 4 \mathrm{a}$ : proactive behavior plays an intermediary role in the relationship between positive leadership and individual innovation performance.

$\mathrm{H} 4 \mathrm{~b}$ : Proactive behavior plays an intermediary role in the relationship between organizational support and individual innovation performance.

Based on the above assumptions, the empirical research framework is summarized as shown in Figure 1: 


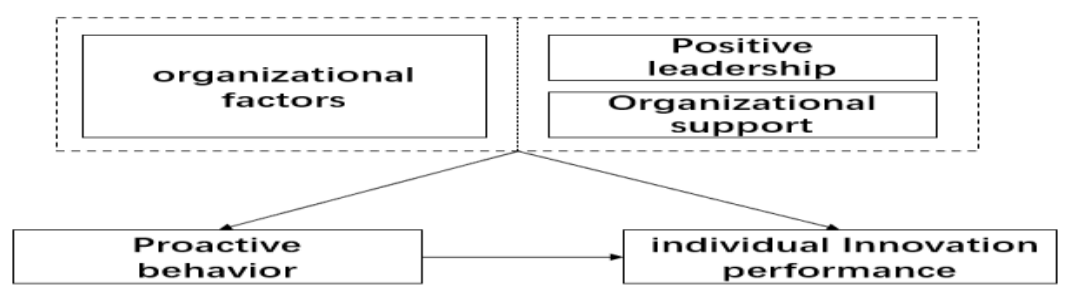

Figure 1 empirical research framework

\section{RESEARCH DESIGN}

\subsection{Research Sample}

Taking the scientific and technological personnel and college teachers engaged in $\mathrm{R} \& \mathrm{D}$ in high-tech enterprises in Dawan District, Guangdong, Hong Kong and Macao as the survey objects, we used the network platform "questionnaire star" to conduct data research, and collected 1050 answers by sending two-dimensional codes through wechat of students, friends and acquaintances, with a recovery rate of $90 \%$ and an effective rate of $100 \%$.

The demographic characteristics of the final effective sample are as follows: (1) gender: male (550, accounting for $52.38 \%$ ) and female (500, accounting for $47.62 \%$ ); (2) Age: age $\leq 25$ years old (20 persons, accounting for $1.9 \%), 25<$ age $\leq 35$ years old ( 380 persons, accounting for $36.19 \%), 35<$ age $\leq 45$ years old (500 persons, accounting for $47.62 \%), 45<$ age $(150$ persons, accounting for $14.29 \%$ ); (3) Education: Junior College (20, accounting for $1.9 \%$ ), undergraduate (280, accounting for $26.67 \%$ ), master (690, accounting for $65.71 \%)$, doctor $(60$, accounting for $5.72 \%)$; (4) Working years: less than 1 year (30 people, accounting for $2.86 \%$ ), $1-5$ years (160 people, accounting for $15.24 \%$ ), 5-10 years (210 people, accounting for $20.0 \%$ ), more than 10 years (650 people, accounting for $61.9 \%$ ).

\subsection{Research Tools}

On the basis of the existing maturity scale, we made the questionnaire title after appropriate adjustment according to needs. All variables were measured by Likert 5-point method.

\subsubsection{Positive leadership.}

Inclusive leaders mainly refer to Carmelie (2010) [5] scale and set three questions from the perspective of openness, usefulness and accessibility, such as "your superiors are willing to listen to new ideas". Transformational leaders mainly refer to the multifactor Behavior Questionnaire (CMLQ) [8] prepared by bass (1985), and set three questions from the three dimensions of leadership charm, personalized care and intellectual stimulation, such as "your superior makes you feel optimistic about the future". Referring to the scale prepared by Aheame et al. (2005) [46], authorized leaders set two topics from the perspectives of promoting participatory decision-making and providing autonomy, such as "your superior allows you to work in your own way".

\subsubsection{Organizational support.}

Mainly referring to the scale developed by Eisenberger et al. (1986) [13] and Ling Wenyun et al. (2006) [16], three topics are set from three aspects: instrumental support, emotional support and welfare support, such as "your unit cares about you and often provides work support".

\subsubsection{Proactive behavior.}

Mainly referring to the scale prepared by Parker (2010) [47], three topics are set from the perspectives of initiative, foresight and innovation, such as "you often discuss and seek resources or support that can realize new ideas".

\subsubsection{Individual innovation performance.}

Referring mainly to the scale prepared by Janssen [48] and Han Yi [49], four topics are set, such as "you will promote your innovative ideas step by step".

\section{DATA ANALYSIS}

\subsection{Reliability Analysis}

We use Cronbach 'alpha to test the reliability of the measurement items. The reliability test results are shown in Table 1.

It can be seen from table 1 that the positive leadership reliability coefficient is 0.923 , the organizational support reliability coefficient is 0.861 , the proactive behavior reliability coefficient is 0.823 , and the individual innovation performance reliability coefficient is 0.881 , all of which are greater than 0.8 . Therefore, it shows that the reliability quality of the research data is high and can be used for further analysis. 
Table 1 Test Value of Cronbach's a Coefficient of Research Variable

\begin{tabular}{clc}
\hline Scale & Cases & Cronbach's a Coefficient \\
\hline Positive leadership & 8 & 0.923 \\
Organizational support & 3 & 0.861 \\
Proactive behavior & 3 & 0.823 \\
Individual innovation & 4 & 0.881 \\
performance & 4 & \\
\hline
\end{tabular}

\subsection{Validity Analysis}

KMO value and Bartlett sphericity test were used for validity verification. The validity test results are shown in Table 2.

It can be seen from table 2 that the KMO value of positive leadership is 0.913 , greater than 0.9 , indicating good validity; The KMO value of organizational support is 0.696 , and the $\mathrm{KMO}$ value of proactive behavior is 0.685 , which is greater than 0.6 , indicating that the validity is acceptable; The KMO value of individual innovation performance is 0.802 , greater than 0.8 , indicating that the validity of the research data is very good. Bartlett's sphericity test of positive leadership, organizational support, proactive behavior and individual innovation performance reached a significant level of 0.000 , which was suitable for factor analysis, indicating that the four scales used in this study had good validity.

Table 2 KMO and Bartlett Values of Study Variables

\begin{tabular}{|c|c|c|c|c|c|}
\hline \multicolumn{2}{|c|}{} & $\begin{array}{c}\text { Positive } \\
\text { leadership }\end{array}$ & $\begin{array}{c}\text { Organizational } \\
\text { support }\end{array}$ & $\begin{array}{c}\text { Proactive } \\
\text { behavior }\end{array}$ & $\begin{array}{c}\text { Individual innovation } \\
\text { performance }\end{array}$ \\
\hline \multicolumn{2}{|c|}{ KMO value } & 0.913 & 0.696 & 0.685 & 0.802 \\
\hline \multirow{2}{*}{$\begin{array}{c}\text { Bartlett } \\
\text { Sphericity } \\
\text { test }\end{array}$} & $\begin{array}{c}\text { Approximate } \\
\text { chi-square }\end{array}$ & 588.562 & 155.640 & 120.646 & 242.078 \\
\cline { 2 - 6 } & $d f$ & 28 & 3 & 3 & 6 \\
\cline { 2 - 6 } & p value & 0.000 & 0.000 & 0.000 & 0.000 \\
\hline
\end{tabular}

\subsection{Homologous Deviation Analysis}

During homology deviation analysis, Confirmatory Factor Analysis (CFA) method is mainly used, which puts all measurement items in one factor and then analyzes them. If the measurement shows that the fitting indexes of the model, such as chi square degree of freedom ratio, RMSEA, RMR and CFI, cannot meet the standard, it indicates that the model fitting is poor, It means that all measured items should not belong to the same factor, so it means that there is no homologous method deviation in the data.

This time, all 18 measurement items are put into one factor for confirmatory factor analysis, and the model fitting indicators are obtained, as shown in Table 3.

Table 3 shows that the chi square degree of freedom value is 4.742 , which is higher than the standard $(<3)$, and the four index values of GFI, CFI, NFI and NNfi are all lower than 0.7 , with obvious deviation from the standard value (greater than 0.9), RMSEA value greater than 0.10 , RMR value greater than 0.05 , which is also the standard value. Other indicators such as AGFI, IFI, PGFI and PNFI are also lower than 0.7 , and the serious deviation is greater than 0.9 , which indicates that the model fitting quality is very poor, and the scale data in this study can not be focused into one factor, that is, there is no common method deviation.

Table 3 CFA Analysis Model Fitting Index

\begin{tabular}{|c|c|c|r|r|r|r|r|r|r|r|}
\hline Index & $\chi^{2}$ & $d f$ & $\mathrm{p}$ & $\chi^{2} / d f$ & $\mathrm{GFI}$ & RMSEA & RMR & CFI & NFI & NNFI \\
\hline Judge Standard & - & - & $>0.05$ & $<3$ & $>0.9$ & $<0.10$ & $<0.05$ & $>0.9$ & $>0.9$ & $>0.9$ \\
\hline Value & 640.109 & 135 & 0.000 & 4.742 & 0.526 & 0.189 & 0.094 & 0.618 & 0.567 & 0.568 \\
\hline Other Index & TLI & AGFI & IFI & PGFI & PNFI & SRMR & AIC & BIC & & \\
\hline Judge Level & $>0.9$ & $>0.9$ & $>0.9$ & $>0.9$ & $>0.9$ & $<0.1$ & 越小越好 & 越小越好 & & \\
\hline Value & 0.568 & 0.400 & 0.624 & 0.416 & 0.500 & 0.167 & 3868.627 & 3964.169 & & \\
\hline
\end{tabular}




\subsection{Correlation Analysis}

Pearson correlation coefficient is mainly used to study the correlation between positive leadership, organizational support, proactive behavior and individual innovation performance. The Pearson values of research variables are shown in Table 4.

Table 4 Pearson Values of Study Variables

\begin{tabular}{|c|c|c|c|c|}
\hline & $\begin{array}{c}\text { Positive } \\
\text { leadership }\end{array}$ & $\begin{array}{c}\text { Organizational } \\
\text { support }\end{array}$ & $\begin{array}{c}\text { Proactive } \\
\text { behavior }\end{array}$ & $\begin{array}{c}\text { Individual innovation } \\
\text { performance }\end{array}$ \\
\hline Positive leadership & 1 & & & \\
\hline Organizational support & $0.715^{\star *}$ & 1 & 1 & 1 \\
\hline Proactive behavior & $0.526^{\star *}$ & $0.596^{\star *}$ & $0.749^{* *}$ & 1 \\
\hline $\begin{array}{c}\text { Individual innovation } \\
\text { performance }\end{array}$ & $0.370^{* *}$ & $0.439^{* *}$ & & \\
\hline
\end{tabular}

It can be seen from table 4 that individual innovation performance and positive leadership, organizational support and proactive behavior, proactive behavior and positive leadership and organizational support are significant $(\mathrm{P}<0.01)$, and the correlation coefficient values are higher than 0.3 , which shows that individual innovation performance and positive leadership, organizational support, proactive behavior, proactive behavior and positive leadership There is a significant positive correlation between organizational support.

\subsection{Regression Analysis and Hypothesis test}

It can be seen from table 4 that the correlation coefficient between positive leadership and organizational support is 0.715 , much greater than 0.6 , and the correlation between them is very high. As independent variables, positive leadership and organizational support are prone to collinearity of independent variables in linear regression analysis, which will lead to serious deviation or even completely opposite conclusions in data research. Therefore, ridge regression, a more scientific research method, is used for regression analysis.

\subsubsection{Ridge regression analysis of positive} leadership, organizational support, proactive behavior and individual innovation performance

In ridge regression analysis, gender, age, working years and educational background are taken as control

Table 5 Ridge Regression Analysis Results of Positive Leadership, Organizational Support, Proactive Behavior and Individual Innovation Performance variables, positive leadership, organizational support, proactive behavior are taken as independent variables, and individual innovation performance is taken as dependent variables. The $\mathrm{K}$ value is taken as 0.990 . The results are shown in Table 5 .

As can be seen from table 5 , the regression coefficient of active leadership is $0.053(\mathrm{t}=2.039, \mathrm{P}=0.044<0.05)$, which means that positive leadership will have a significant positive impact on individual innovation performance. Therefore, it is assumed that H1a: there is a significant positive correlation between positive leadership and individual innovation performance. The regression coefficient of organizational support is 0.076 $(\mathrm{t}=3.100, \mathrm{P}=0.003<0.01)$, which means that organizational support will have a significant positive impact on individual innovation performance. Therefore, it is assumed that $\mathrm{Hlb}$ : there is a significant positive correlation between organizational support and individual innovation performance, and $\mathrm{H} 1$ : there is a significant positive correlation between organizational factors and individual innovation performance.

It can also be seen from table 5 that the regression coefficient of proactive behavior is $0.327(\mathrm{t}=9.254, \mathrm{P}=$ $0.000<0.01$ ), which means that proactive behavior will have a significant positive impact on individual innovation performance. It also proves that the hypothesis $\mathrm{H} 2$ : proactive behavior has a significant positive correlation with individual innovation performance.

\begin{tabular}{|c|c|c|c|c|c|c|c|c|}
\hline & \multicolumn{2}{|c|}{$\begin{array}{l}\text { Non standardized } \\
\text { coefficient }\end{array}$} & $\begin{array}{c}\text { Standardization } \\
\text { coefficient }\end{array}$ & \multirow{2}{*}{ t } & \multirow{2}{*}{$p$} & \multirow{2}{*}{$R^{2}$} & \multirow{2}{*}{$\begin{array}{r}\text { Adjust } \\
R^{2}\end{array}$} & \multirow{2}{*}{$F$} \\
\hline & $B$ & $\begin{array}{l}\text { Standard } \\
\text { error Beta }\end{array}$ & Beta & & & & & \\
\hline constant & 1.900 & 0.248 & - & 7.656 & $0.000 * *$ & \multirow{5}{*}{ 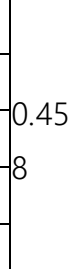 } & \multirow{5}{*}{0.419} & \multirow{5}{*}{$\begin{array}{c}f(7,97)= \\
11.728, \\
p=0.000\end{array}$} \\
\hline Gender & -0.058 & 0.042 & -0.050 & -1.359 & 0.177 & & & \\
\hline Age & 0.037 & 0.026 & 0.046 & 1.395 & 0.166 & & & \\
\hline Working years & 0.034 & 0.023 & 0.050 & 1.495 & 0.138 & & & \\
\hline education & -0.011 & 0.037 & -0.011 & $\mid-0.306$ & 0.760 & & & \\
\hline
\end{tabular}




\begin{tabular}{|c|c|c|c|c|c|c|c|c|}
\hline & \multicolumn{2}{|c|}{$\begin{array}{l}\text { Non standardized } \\
\text { coefficient }\end{array}$} & \multirow{2}{*}{$\begin{array}{c}\begin{array}{c}\text { Standardization } \\
\text { coefficient }\end{array} \\
\text { Beta } \\
\end{array}$} & \multirow{2}{*}{$t$} & \multirow{2}{*}{$p$} & \multirow{2}{*}{$R^{2}$} & \multirow{2}{*}{$\begin{array}{r}\text { Adjust } \\
R^{2}\end{array}$} & \multirow{2}{*}{$F$} \\
\hline & $B$ & $\begin{array}{l}\text { Standard } \\
\text { error Beta }\end{array}$ & & & & & & \\
\hline $\begin{array}{c}\text { Positive } \\
\text { leadership }\end{array}$ & 0.053 & 0.026 & 0.068 & 2.039 & $0.044^{*}$ & & & \\
\hline $\begin{array}{c}\text { Organizational } \\
\text { support }\end{array}$ & 0.076 & 0.024 & 0.100 & 3.100 & $0.003 * \star$ & & & \\
\hline $\begin{array}{l}\text { Proactive } \\
\text { behavior }\end{array}$ & 0.327 & 0.035 & 0.323 & 9.254 & $0.000 * \star$ & & & \\
\hline \multicolumn{9}{|c|}{ Dependent variable: individual innovation performance } \\
\hline \multicolumn{9}{|c|}{${ }^{*} p<0.05 * * p<0.01$} \\
\hline
\end{tabular}

4.5.2. Ridge regression analysis of active leadership, organizational support and proactive behavior
In Ridge regression analysis, gender, age, working years and educational background are taken as control variables, positive leadership and organizational support are taken as independent variables, and proactive behavior is taken as dependent variable. The $\mathrm{K}$ value is taken as 0.990 . The results are shown in Table 6 .

Table 6 Ridge Regression Analysis Results of Positive Leadership,Organizational Support and Proactive Behavior

\begin{tabular}{|c|c|c|c|c|c|c|c|c|}
\hline & \multicolumn{2}{|c|}{$\begin{array}{c}\text { Non standardized } \\
\text { coefficient }\end{array}$} & \multirow{2}{*}{$\begin{array}{c}\begin{array}{c}\text { Standardization } \\
\text { coefficient }\end{array} \\
\text { Beta } \\
\end{array}$} & \multirow{2}{*}{$t$} & \multirow[b]{2}{*}{$p$} & \multirow{2}{*}{$R^{2}$} & \multirow{2}{*}{$\begin{array}{l}\text { Adjust } \\
R^{2}\end{array}$} & \multirow{2}{*}{$F$} \\
\hline & $B$ & \begin{tabular}{|c|} 
Standard \\
error Beta
\end{tabular} & & & & & & \\
\hline constant & 2.395 & 0.236 & - & 10.168 & $0.000^{\star \star}$ & \multirow{7}{*}{0.336} & \multirow{7}{*}{0.296} & \multirow{7}{*}{$\begin{array}{l}F(6,98)= \\
8.281 \\
p=0.000\end{array}$} \\
\hline Gender & -0.001 & 0.046 & -0.001 & -0.018 & 0.986 & & & \\
\hline Age & 0.042 & 0.029 & 0.053 & 1.459 & 0.148 & & & \\
\hline Working years & 0.022 & 0.025 & 0.033 & 0.904 & 0.368 & & & \\
\hline education & 0.011 & 0.040 & 0.011 & 0.268 & 0.789 & & & \\
\hline Positive leadership & 0.141 & 0.029 & 0.182 & 4.920 & $0.000^{\star *}$ & & & \\
\hline $\begin{array}{c}\text { Organizational } \\
\text { support }\end{array}$ & 0.176 & 0.028 & 0.235 & 6.383 & $0.000^{* *}$ & & & \\
\hline \multicolumn{9}{|c|}{ Dependent variable: proactive behavior } \\
\hline \multicolumn{9}{|c|}{${ }^{\star} p<0.05{ }^{* \star} p<0.01$} \\
\hline
\end{tabular}

As can be seen from table 6 , the regression coefficient of positive leadership is $0.141(\mathrm{t}=4.920, \mathrm{P}=0.000<$ 0.01 ), which means that positive leadership will have a significant positive impact on proactive behavior. Therefore, it is assumed that H3a: there is a significant positive correlation between positive leadership and proactive behavior. The regression coefficient of organizational support is $0.176(\mathrm{t}=6.383, \mathrm{P}=0.000<$ 0.01 ), which means that organizational support will also have a significant positive impact on proactive behavior. Therefore, assuming that $\mathrm{H} 3 \mathrm{~b}$ : organizational

Table 7 shows the mediating effect test of proactive behavior for the impact of positive leadership on individual innovation performance. The $95 \%$ interval does not include the number 0 ( $95 \%$ CI: $0.200 \sim 0.438$ ). Therefore, it shows that proactive behavior has an support has a significant positive correlation with proactive behavior, it is certainly true that $\mathrm{H} 3$ : organizational factor has a significant positive correlation with proactive behavior.

\subsection{Mediating effect Test}

The bootstrap sampling test method is used to study the intermediary effect. The sampling times are 5000 times. The results are shown in Table 7.

mediating effect when the impact of positive leadership on individual innovation performance, and positive leadership will first affect proactive behavior, Then, proactive behavior is used to affect individual innovation performance, so $\mathrm{H} 4$ is assumed.

Table 7 relevant values of bootstrap sampling inspection method

\begin{tabular}{|c|c|c|c|c|c|c|}
\hline Items & Effect & Boot SE & BootLLCI & BootULCI & $Z$ & $P$ \\
\hline $\begin{array}{c}\text { Positive leadership } \Rightarrow \text { proactive } \\
\text { behavior } \Rightarrow \text { individual innovation }\end{array}$ & 0.318 & 0.061 & 0.200 & 0.438 & 5.196 & 0.000 \\
\hline
\end{tabular}




\begin{tabular}{|c|c|c|c|c|c|c|}
\hline Items & Effect & Boot SE & BootLLCl & BootULCl & $Z$ & $P$ \\
\hline performance & & & & & & \\
\hline $\begin{array}{c}\text { Organizational suppor } \Rightarrow \\
\text { proactive behavior } \Rightarrow \text { individual } \\
\text { innovation performance }\end{array}$ & 0.342 & 0.061 & 0.223 & 0.463 & 5.609 & 0.000 \\
\hline $\begin{array}{c}\text { Note: BootLLCI refers to the lower limit of 95\% interval of bootstrap sampling, and BootULCI refers } \\
\text { to the upper limit of 95\% interval of bootstrap sampling. }\end{array}$ \\
$\quad$
\end{tabular}

\section{CONCLUSION}

Angle innovation. Previous studies have considered the role of inclusive leadership, transformational leadership and empowerment leadership on individual innovation performance and proactive behavior. In this study, we innovatively integrate the three leadership styles through the concept of positive leadership, so that we can consider the role of leadership on individual proactive behavior and innovation performance from a higher level and broader perspective.

It is confirmed that the positive leadership and support environment in the organization is significantly positively correlated with individual proactive behavior and innovation performance. Through empirical methods, we have verified the significance of positive leadership and support environment in the organization to individual proactive behavior and innovation performance, and also explored the significance of individual scientific and technological employees, as the main body of enterprise innovation, taking advantage of their proactive behavior to actively adapt and transform the environment, create higher individual innovation performance and realize enterprise performance, so as to expand individual Research on organization in enterprise innovation situation.

It is confirmed that proactive behavior plays an intermediary role in the relationship between positive leadership and support factors and individual innovation performance. Through empirical methods, we verify that although the positive leadership and support environment in the organization can play a role in individual innovation performance, it mainly depends on the intermediary role of employees' individual proactive behavior, which not only deepens the research on the impact of employees' individual proactive behavior, but also widens the path for enterprises to improve employees' individual innovation performance

\section{ACKNOWLEDGMENTS}

Research platform of Guangdong provincial Department of education 2018 characteristic innovation project Innovation proactive behavior development and innovation performance improvement of scientific and technological personnel -a case study of high-tech enterprises in Guangdong-Hongkong-Macao Greater
Bay Area (2018GWTSCX051).

\section{A Brief Introduction to the Author}

Li Chunhui (1973.2 -), male, from Guangde, Anhui Province, China, master's degree, lecturer of Guangzhou Huashang Vocational College, research direction: organizational behavior, marketing management, vocational education.

\section{REFERENCES}

[1]Sun Rui, Shi Jintao. Summary of research on Influencing Factors of enterprise innovation organizational behavior [J]. China human resources development, 2006, (7): 14-19.

[2]Shin Y, Kim M J. Antecedents and Mediating Mechanisms of Proactive Behavior: Application of the Theory of Planned Behavior [J]. Asia Pacific Journal of Management, 2015, 32(1):289-310.

[3]Huang Liang, Peng Biyu. Influence mechanism of job well-being on Employee Innovation Performance -a multi-level regulated intermediary model [J]. Nankai management review, 2015,18 (02):15-29.

[4]Luo Xingpeng, Zhang Qianxiang. New trends in active organizational learning: a review of positive leadership research [J]. Science and technology and economy, 2018,31 (05): 81-85.

[5]Carmeli A,ReiterPalmon R,Ziv E.Inclusive Leadership and Employee Involvement in Creative Tasks in the Workplace: the Mediating Role of Psychological Safety [J],Creativity Research Journal,2010,22(3):250-260.

[6]Yao Minghui, Li Yuanxu. Research on the mechanism of inclusive leadership on employee innovation behavior [J]. Scientific and technological progress and countermeasures, 2014 (10):6-9.

[7]Fang Yangchun. The impact of inclusive leadership style on team performance -- the mediating role based on employees' self-efficacy [J]. Scientific research management, 2014 (5): 152 - 160.

[8]Bass B M. Leadership and Performance Beyond Expectations [M]. New York: Free Press, 1985: 256.

[9]Deluga RJ,SouzaJ.The effects of transformational and 
transactional leadership styles on the influencing behaviour of subordinate police officers [J].Journal of Occupational Psychology,2011,64(1): 49-55.

[10]Amundsen S,Martinsen 0L.Empowering leadership Construct clarification, conceptualization, and validation of a new scale $[\mathrm{J}]$. The Leadership Quarterly, 2014,(3).

[11]Amabile T M, Schatzel E A, Moneta G B, et al. Leader behaviors and the work environment for creativity: Perceived leader support [J]. Leadership Quarterly, 2004, (1).

[12]Wang Zhen, long Yufan, Peng Jian. Negative effects of positive leadership: research theme, analytical perspective and theoretical mechanism [J]. Progress in psychological science, 2019,27 (06): 1123-1140.

[13]Eisenberger R, Huntington R, Huntington S, Sowa D. Perceived organizational support $[\mathrm{J}]$. Journal of Applied Psychology, 1986,71 (2):500-507.

[14] George J M, Reed T F, Ballard K A. Contact with AIDS patients as a source of work - related distress: effects of organizational and social support [J]. Academy of Man $\neg$ agement Journal, 1993,36: 157 -171 .

[15]Bell,S.J, Menguc,B.The Employee-organization Relationship, Organizational Citizenship Behavior, and Superior Service Quality [J]. Journal of Retailing, 2002, 78:131-146.

[16]Ling Wenyun, Yang Haijun, Fang Liluo. Organizational support of enterprise employees [J]. Journal of psychology, 2006, 38 (2): 281-287.

[17]Amabile G, Knippenberg D V, Zhou J. A CrossLevel Perspective on Employee Creativity : Goal Orientation , Team Learning Behavior,and Individual Creativity [J].Academy of Management Journal, 1996, 52(2): 280-293.

[18]Janssen R,Aselage J.Incremental Effects of Reward on Experienced Performance Pressure : Positive Outcomes for Intrinsic Interest and Creativity [J].Journal of Organizational Behavior,2000,30(1): 95-117.

[19]Han Yi, Liao Jianqiao. Review on the theory of organizational member performance structure [J]. Journal of management science, 2006, 9 (2): 86-94.

[20]Heng Yuanyuan. Research on the impact of creativity on employee innovation performance [D]. Hunan University, 2012,36-42.

[21]Chen Wenpei. The impact of leadership style on Innovation Performance: taking innovation behavior as an intermediary variable $[\mathrm{J}]$. Economic longitude and latitude, 2014,31 (05): 93-97.

[22]Fang Yangchun, Jin Huihong. Empirical Study on the impact of inclusive leadership style on the performance of university scientific research teams [J]. Technology and economy, 2014,33 (4): 53-57.

[23]Zhong Lifeng, Wang Zhen, Li Mei, Li Chaoping. Research on the impact of transformational leadership and psychological capital on employees' job performance [J]. Journal of management, 2013,10(04): 536-544.

[24]Chen Z. X., Aryee S. Delegation and Employee Work Outcomes: An Examination of the Cultural Context of Mediating Processes in China [J]. Academy of Management Journal, 2007, 50(1): 226-238.

[25]Janssen O,Van Yperen N W.Employee's goal orientations, the quality of leader-member exchange, and the outcomes of job performance and job satisfaction [J]. Academy of Management Journal, 2004,27(3):368-384.

[26]Yu C,Frenkel S J.Explaining task performance and creativity from perceived organizational support theory: Which mechanisms are more important [J].Journal of Organizational Behavior,2013,34(8): 1165-1181.

[27]Crant S J. Proactive Behavior in Organizations [J]. Journal of Management, 2000, 26 (3): 435 -462.

[28]Campbell D J. The Proactive Employee: Managing Workplace Initiative $[\mathrm{J}]$. Academy of Management Executive, 2000, 14 (3): 52-66.

[29] Fay D, Frese M. The concept of personal initiative: An overview of validity studies [J]. Human Performance, 2001, 14(1):97-124.

[30] Parker S K, Wall T D, Cordery J. Future work design research and practice: Towards an elaborated model of work design $[\mathrm{J}]$. Journal of Occupational and Organizatio $\neg$ nal Psychology, 2001,74(4):413-440.

[31]Belschak F D,Hartog D N, Fay D. Exploring Positive, Negative and Context-dependent Aspects of Proactive Behaviors at Work [J]. Journal of Oc $\neg$ cupational and Organizational Psychology, 2010, 83 (2): 267 -273.

[32]Fuller, J. B., Jr., Marler, L. E., \& Hester, K. Bridge building within the province of proactivity. [J].Journal of Organizational Behavior, 2012, 33, 1053-1070.

[33]Frese, M.The word is out: We need an active performance concept for modern workplaces. $[\mathrm{J}]$ Industrial and Organizational Psychology: Perspectives on Science and Practice,2008,1, $67-$ 69. 
[34]Janssen O, Job demands, perceptions of effort reward fairness and innovative work behaviour [J]. Journal of Occupational and organizational psychology, 2000, 73(3): 287-302.

[35]Liu Yang,Zhu Wei,Zhao Shuming.Research on the influence of inclusive leadership style on employment relationship atmosphere and employees' active behavior [J].Journal of management,2016,13 (10):1482-1489.

[36]Strauss K,Griffin M A,Rafferty A E.Proactivity directed toward the team and organization:the role of leadership,commitment and Role-breadth Selfefficacy[J].British Journal of Management 2010,20(3):279-291.

[37]Den Hartog D N,Belschak F D.When does transformational leadership enhance employee proactive behavior? The role of autonomy and role breadth self-efficacy[J].Journal of Applied Psychology,2012,97(1): 194-202.

[38] Yin Jun, Huang mingpeng. Comparative study on the impact of intra organizational exchange relationship on employee performance in China $[\mathrm{J}]$. Frontier theory, 2011, (37): 17-21.

[39]Tian Xizhou, Xie Jinyu. The impact of organizational support on employees' work behavior: An Empirical Study on the mediating role of psychological capital [J]. Nankai management review, 2010 (1):23-29.

[40]Eisenberger, Moshe. An exact element method [J]. International Journal for Numerical Methods in Engineering, 1990, 30(2):363-370.

[41]Mumford M D. Fried Y. Give them what they want or give them what they need? Ideology in the study of leadership [J].Journal of organizational behavior, 2014,35 (4): 622-634.

[42]Gumusluoglul, IlsevL A. Transformational leadership, creativity, and organizational innovation [J]. Journal of Busi $\neg$ ness Research,2009,62(4): 461 473.

[43]Amabile T. M, Conti R., Coon H., et al. Assessing the Work Environment for Creativity [J]. Academy of Management Journal. 1996, 39(5):1154-1184.

[44]Mei Huiying. Research on the influence mechanism of shared leadership style on employees' innovative behavior [D]. Southwest University of Finance and economics, 2011.

[45]McKenny A F, Short J c, Payne G T. Using Computer-Aided Text Analysis to Elevate Constructs An Illustration Using Psychological Capital [J]. Organizational Research Methods,2013,16(1):152-184.
[46]Aheame , M., Mathieu, J.? \& Rapp, A. To empower or not to empower your sales force? An empirical examination of the influence of leadership empowerment behavior on customer satisfaction and performance $[\mathrm{J}]$. TTie Journal of Applied Psychology, 2005,90(5): 945-955.

[47]Parker, S. K., Collins, C.G.. Taking Stock: Integrating and Dif $\neg$ ferentiating Multiple Proactive Behaviors. [J]. Journal of Manage $\neg$ ment, 2010, 36(2): 633-662.

[48]Janssen C. E, Gilson L. L, Blum TC. Interactive Effects of Growth Need Strength, Work Context, and Job Complexity on Selfreported Creative Performance[J].Academy of Management Journal,2004,52(3): 349-505.

[49]Han Yi, Liao Jianqiao, long Lirong. Construction and empirical research of employee job performance structure model $[\mathrm{J}]$. Journal of management science, 2007 (05): 62-77. 